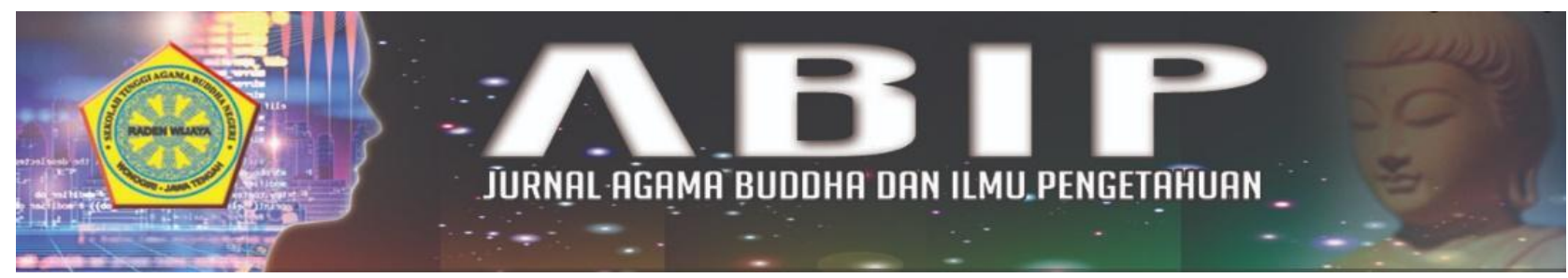

\title{
ANALISIS EKONOMI SYARIAH MENURUT SUDUT PANDANG AGAMA BUDDHA
}

\author{
Tulas Maitriya \\ Sekolah Tinggi Agama Buddha (STAB) Kertarajasa \\ tulasmaitriya@gmail.com
}

\begin{abstract}
Abstrak
Ekonomi syariah merupakan ajaran yang mengedepankan nilai-nilai agama serta etika dalam bermuamalah, yang memberikan nilai keuntungan secara adil kepada kedua pihak yang bersangkutan serta membagikan kerugian yang ada sehingga tidak diberatkan kepada salah satu pihak saja. Atas dasar hal tersebut, penelitian ini dibuat untuk mencari tahu adanya korelasi antara ekonomi Syariah dengan ekonomi dalam agama Buddha. Metode penelitian didasarkan pada kajian pustaka dan menggunakan metode yang relevan dengan teori yang ada. Sumber data yang digunakan dalam penelitian ini mengambil sumber primer dan sekunder. Sumber primer yaitu Al-Quran dan Hadis, Tipitaka. Sumber sekunder yaitu buku-buku populer dan sumber penunjang lainnya yang relevan dengan masalah yang dibahas. Teknik analisis data yang digunakan dalam penyusunan skripsi sebagian besar menggunakan cara menarik kesimpulan dengan cara deduktif. Secara deduktif yaitu pengumpulan data dari hal-hal yang bersifat umum menjadi hal-hal yang bersifak khusus, serta korelatif yang bersifat mempunyai hubungan timbal balik satu dengan yang lain. Dalam penelitian ini ditemukan adanya korelasi antara Ekonomi dalam Islam maupun Buddhis yaitu dilakukan dengan usaha tanpa merugikan diri sendiri, orang lain maupun makhluk lain. Dalam sudut pandang agama Buddha ditunjukkan bahwa ekonomi yang dilakukan harus melalui jalan yang benar dan sah, sesuai dengan yang diajarkan yaitu dengan berpedoman pada jalan mulia berunsur delapan yaitu mata pencaharian benar. Ekonomi buddhis tidak hanya mempertimbangkan pada kebahagiaan diri sendiri, melainkan juga memperhatikan pihak lain.
\end{abstract}

Kata kunci: Ekonomi Syariah; Ekonomi Buddhis

\begin{abstract}
Sharia economics is a teaching that puts forward religious and ethical values in muamalah, which provides a fair value of benefits to both parties concerned and distributes existing losses so that they are not burdened with only one party. On this basis, this study was made to find out the correlation between Islamic economics and economics in Buddhism. The research method is based on literature review and uses methods that are relevant to existing theories. Sources of data used in this study took primary and secondary sources. Primary sources are Al-Quran and Hadith, Tipitaka. Secondary sources are popular books and other supporting sources that are relevant to the problem being discussed. The data analysis technique used in the preparation of the thesis mostly uses a deductive way of drawing conclusions. Deductively, namely the collection of data from things that are general to things that are specific, as well as correlatives that have a reciprocal relationship with one another. In this research, it was found that there was a correlation between Economics in Islam and Buddhism, which was carried out with effort without harming oneself, others or other creatures. From the point of view of Buddhism, it shows that the economy that is carried out must go through the right and legitimate path, according to what is taught, namely by being guided by the noble eightfold path, namely right livelihood. Buddhist economics not only considers one's own happiness, but also considers others.
\end{abstract}

Keywords: Sharia economics; Buddhist economics 


\section{PENDAHULUAN}

Perekonomian merupakan aktivitas ekonomi yang tidak bisa terlepas dari kehidupan manusia di belahan bumi manapun. Dalam perkembangannya perekonomian mengalami transformasi, modernisasi bahkan inovasi untuk pengaplikasian penerapannya, dan tentu saja bersumber pada teori-teori ataupun dasar-dasar ekonomi yang telah ada. Namun, dalam praktiknya teori-teori ekonomi bersifat fleksibel sesuai kebutuhan dari suatu negara ataupun lingkup yang mengaplikasikannya.

Perubahan umum perekonomian yang dialami suatu negara sering menjadi bahan pembicaraan, baik di kalangan ilmuwan, ekonom, pejabat pemerintah, maupun masyarakat yang tertarik sebagai pemerhati ekonomi. Berbagai media massa sering memuat berita besar mengenai perubahan ekonomi yang dialami suatu negara, seperti inflasi, pengangguran, kesempatan kerja, hasil produksi, dan penanaman modal.

Ekonomi syariah sebagai suatu ilmu pengetahuan lahir melalui proses pengkajian ilmiah yang panjang, di mana pada awalnya terjadi sikap pesimis terkait eksistensi ekonomi syariah dalam kehidupan masyarakat saat ini. Hal ini terjadi karena di masyarakat telah terbentuk suatu pemikiran bahwa harus terdapat pembagian antara agama dengan keilmuan. Dalam hal ini termasuk di dalamnya ilmu ekonomi, namun sekarang hal ini sudah mulai terkikis. Para ekonom barat pun mulai mengakui eksistensi ekonomi syariah sebagai suatu ilmu ekonomi yang memberi warna kesejukan dalam perekonomian dunia di mana ekonomi syariah dapat menjadi sistem ekonomi alternatif yang mampu mengingatkan kesejahteraan umat, di samping sistem ekonomi kapitalis dan sosialis yang telah terbukti tidak mampu meningkatkan kesejahteraan umat

Ekonomi syariah merupakan ajaran yang mengedepankan nilai-nilai agama serta etika dalam bermuamalah, yang memberikan nilai keuntungan secara adil kepada kedua pihak yang bersangkutan serta membagikan kerugian yang ada sehingga tidak diberatkan kepada salah satu pihak saja. Berbeda dengan ekonomi konvensional yang memiliki prinsip mencari keuntungan sebesar-besarnya dengan menggunakan cara apapun dan tidak mengindahkan keadilan sesama dalam persaingannya di dunia ekonomi. Hal tersebut sudah pasti memberikan keresahan kepada umat Islam yang ikut andil dalam kegiatan tersebut. Sehingga ekonomi syariah menjawab segala keresahan umat Islam dalam melakukan kegiatan ekonomi tanpa ada rasa khawatir dan was-was karena sudah jelas bahwa dalam ekonomi syariah dilarang menggunakan caracara yang tidak benar, jauh dari yang bersifat maysir, gharar, haram dan riba, sedangkan ekonomi konvensional tidak mengenal hal tersebut.

Ekonomi syariah dibangun atas dasar agama Islam, karenanya ia merupakan bagian tak terpisahkan (integral) dari agama Islam. Sebagai derivasi dari agama Islam, Ekonomi syariah akan mengikuti agama Islam dalam berbagai aspeknya. Islam adalah sistem kehidupan (way of life), di mana Islam telah menyediakan berbagai perangkat aturan yang lengkap bagai kehidupan manusia termasuk dalam bidang ekonomi. Setiap manusia bertujuan mencapai kesejahteraan dalam hidupnya, namun manusia memiliki pengertian yang berbeda-beda tentang kesejahteraan. Dalam berbagai literatur Ilmu Ekonomi konvensional dapat disimpulkan bahwa tujuan manusia memenuhi kebutuhannya atas barang dan jasa adalah untuk mencapai kesejahteraan (well being). Manusia menginginkan kebahagiaan dan kesejahteraan dalam hidupnya, dan untuk inilah ia berjuang dengan segala cara untuk mencapainya.

$$
\text { Kesejahteraan manusia yang }
$$

dikemukakan di dalam Al-Qur'an berhubungan dengan kenikmatan dan kesengsaraan manusia di akhirat, dan kriteria obyektif sesuai dengan kebutuhan-kebutuhan ekonomi seperti makanan, pendidikan perumahan, barang-barang dan jasa-jasa lainnya dan komoditi-komoditi no-materil seperti kesenantiasaan, cinta dan kasih sayang antara suami istri. Konsep ini mengutamakan pemuasan terhadap "keinginan-keinginan yang bermanfaat", menolak "keinginankeinginan yang tidak bermanfaat, dan 
mendorong manusia untuk mengerahkan sumber-sumber manusiawi dan materilnya untuk memenuhi "keinginan-keinginan masyarakat".

Al-Qur'an mempersiapkan manusia untuk menghadapi gelombang kehidupan dengan penderitaan psikis seminal mungkin atau sama sekali tanpa penderitaan karena kematian, kehilangan harapan. Jadi, kriteria Islam mengenai kesejahteraan manusia bersifat fisik, material. Al-Qura'an menciptakan motif agar manusia dapat merasakan kenikmatan psikis karena melakukan pengeluaran untuk kepentingan pribadi dan negara yang bersifat altruistik, jadi bukan karena meyakini dan melaksanakan rumusan-rumusan ekonomi seperti pajakpajak yang tidak merangsang dan sedikit manfaatnya. Sains kesusilaan ekonomi syariah berusaha memenuhi dan memodifikasikan keinginan-keinginan, hasrat-hasrat dan kesukaan-kesukaan manusia. Sebuah prinsip penting mengenai mentalitas kultural Islam yang integral adalah bahwa kesejahteraan ekonomi manusia bukanlah merupakan alat penting agar ia dapat kesejahteraannya yang total.

Penjelasan ekonomi menurut agama Buddha seperti halnya dalam ekonomi syariah tidak disyahkan sebagai aturan mutlak. Namun di dalam agama Buddha dapat kita lihat di sutta-sutta banyak mengulas mengenai ekonomi secara garis besar. Dalam pandangan para pendukungnya, ekonomi Buddhis bertujuan untuk menghilangkan kebingungan tentang apa yang berbahaya dan apa yang bermanfaat dalam berbagai kegiatan manusia yang melibatkan produksi dan konsumsi barang dan jasa, yang pada akhirnya berusaha mewujudkan manusia yang dewasa secara etis.

\section{METODE}

Metode penelitian didasarkan pada kajian pustaka dan menggunakan metode yang relevan dengan teori yang ada. Metode yang digunakan dalam penyusunan skripsi ini adalah kajian kepustakaan atau library research. Penelitian pustaka ini sekaligus memanfaatkan sumber pustaka untuk memperoleh data penelitian. Sesuai dengan metode yang digunakan yaitu library research, maka metode yang digunakan dalam penelitian adalah metode deduktif, yaitu menarik kesimpulan dari umum menuju pernyataanpernyataan khusus dengan menggunakan penalaran atau rasio (Sudjana, 1988:5). Metode penelitian ini meliputi (1) tempat dan waktu, (2) pengumpulan data, (3) teknik analisa data, (4) kerangka konsep.

\section{HASIL DAN PEMBAHASAN \\ Korelasi antara Ekonomi Syariah dengan Ekonomi Buddhis}

Proses kegiatan ekonomi merupakan proses kegiatan manusia yang bertujuan untuk memenuhi kebutuhan hidupnya. Dalam melaksanakan hal tersebut, diperlukanlah suatu manajemen yang terstruktur seperti perencanaan, pengorganisasian, pengarahan serta pengawasan dengan maksud untuk mencapai tujuan yang diingikan oleh pihak yang berkecimpung di dunia ekonomi. Maksud melakukan ekonomi ialah untuk meraup keuntungan sebesar-besarnya dengan berorientasi pada kebutuhan pokok seperti tempat tinggal, makanan, pakaian, dan kesehatan, hal demikian bisa saja memicu seseorang ataupun beberapa untuk bertindak menyimpang dari nilai moral religius.

\section{Korelasi dari Sudut Pandang Definisi}

Ekonomi islam merupakan bagian yang tak terpisahkan dari konsep ajaran islam. Dalam islam aktivitas ekonomi yang diniatkan dan ditujukan untuk kemaslahatan dinilai sebagai ibadah. Oleh karena itu, mempelajari ekonomi islam dan menjalankan aktifitas ekonomi secara islami menjadi suatu keharusan bagi umat islam. Sedangkan dalam dunia ekonomi ada beberapa karakteristik ekonomi islam, yaitu harta kepunyaan allah dan manusia merupakan khalifah atas harta (1) ekonomi terkait dengan akidah, syariah (Hukum), (2) keseimbangan antara kerohanian dan kebendaan, (3) kebebasan individu dijamin dalam islam, (4) negara diberi wewenang turut campur dalam perekonomian, (5) bimbingan konsumsi, (6) petunjuk investasi, (7) Zakat, (8) larangan riba (Rivai, 2009:169).

Sedangkan menurut pandangan Buddhis, ekonomi memiliki arti pembahasan tentang cara untuk memperoleh suatu 
kekayaan dengan mata pencaharian benar, cara mengatur pendapatan hingga cara menggunakan kekayaan itu sendiri. Cara yang digunakan dengan cara yang sah dan benar, tidak merugikan diri sendiri, orang lain mapun makhluk lain. Ekonomi dalam agama Buddha ini ditujukan kepada mereka yang menjalani kehidupan berumah-tangga. Melakukan ekonomi merupakan kebutuhan untuk memenuhi kesejahteraan manusia agar bisa menjalani hidupnya dengan nyaman, sebab Sang Buddha sendiri menyatakan dalam Anguttara Nikāya, VI: 45 bahwa kemiskinan adalah suatu keadaan yang celaka dalam kehidupan. Jika manusia berada dalam kemiskinan, maka seseorang terjerumus pada berbagai kesulitan seperti; terbelit hutang, harus membayar bunga, ditagih hutang, menjadi bangkrut dan tidak menutup kemungkinan masuk penjara karena tidak mampu membayar hutang. Kesulitan itu memaksa orang melakukan kejahatan dengan mencuri, menipu, merampas, merampok dan lain sebagainya. Satu-satunya jalan untuk menghidar dari lima keadaan ini dan kemungkinan kejahatan dapat dilakukan adalah memiliki ekonomi yang sejahtera.

\section{Korelasi dari Paradigma-paradigma yang Melandasi}

Dalam korelasi paradigma-paradigma yang melandasi terdapat prinsip dasar adanya ekonomi Islam maupun Buddhis. Prinsip dasar tersebut sebagai berikut:

Prinsip dasar ekonomi Islam terdiri dari 11 macam:

1. Kesadaran terhadap sisi alam

Dalam pandangan Islam, Allah SWT menciptakan manusia ke bumi dan dipercaya untuk menjaga, memelihara serta memakmurkan bumi.

2. Kekayaan manusia dan prosedur pengelolaan

Islam mengetahui bahwa segala yang mereka miliki saat hidup di dunia ini adalah titipan dari sang Pencipta.

3. Menghemat sumber daya

Ekonomi Islam menganjurkan pelakunya menjadi hidup hemat dan tidak boros (Mubazir).

4. Mencapai kepuasan dan keuntungan secara Halal
Kepuasan pelaku ekonomi dapat dicapai dengan proses yang benar dan bahan yang halal (baik).

5. Menepati ketentuan meterologi

Kebanyakan bisnis yang muncul dengan memperhitungkan satuan panjang, berat, volume, kadar dan sebagainya.

6. Jujur dan Transparan

Dalam segala aspek aktivitas manusia, kejujuran adalah modal yang paling berharga. Dengan modal itikad baik, manusia dapat hidup dan bekerja dengan tenang dan tenteram. Itu sebabnya, pada prinsipnya, semua orang suka jujur.

7. Menghindari Sistem Ijon dan Transaksi Spekulatif

Pada dasarnya, tidak ada sistem ekonomi di dunia yang menyukai sistem Ijon (perbudakan) dan perdagangan spekulatif.

8. Memperlakukan tenaga kerja sebagai mitra

Dalam ekonomi Islam, tenaga kerja adalah mitra, bukan hanya faktor produksi. Oleh karena itu, kepentingannya menjadi perhatian utama.

9. Menghindari riba dan perdagangan uang Dalam prinsip ekonomi, uang tidak menciptakan uang, tetapi uang menciptakan barang dengan operasi hukum dan kepatuhan Syariah. Dengan demikian, dalam ekonomi Islam, fungsi ekonomi Islam adalah bahwa uang hanya sebagai alat tukar, bukan sebagai penyimpan kekayaan, juga bukan sebagai spekulasi.

10. Menghindari paham Materialisme

Ekonomi Islam menyukai gaya hidup sederhana, tidak boros, tidak pamer, tidak sombong dengan kekayaan, bahkan penggunaan harta dan materi secara rasional bukanlah segalanya.

11. Menghindari sistem monopoli

Sistem ekonomi Islam menawarkan hak dan kesempatan yang sama kepada semua orang dalam bisnis dan pekerjaan yang berbeda, selama itu legal dan legal, sehingga setiap pelaku ekonomi atau pengusaha tidak mutlak, atas dasar sumber daya alam sebagai milik bersama.

Prinsip dasar dalam ekonomi Buddhis, yaitu: 
1. Mata Pencaharian Benar (sammā-ajiva) merupakan poin dari Jalan Mulia Berunsur Delapan (ariya atthangika magga). Hal tersebut merupakan dasar untuk membangun ekonomi Buddhis. Sistem perekonomian akan semakin kuat dan kokoh apabila segala bentuk usaha dilakukan dengan cara yang benar.

2. Tidak anti terhadap perdagangan dan monopoli asalkan menganut paham 'Jalan Tengah'. Dhamma mengajarkan untuk tidak ekstrim dalam hal kepemilikan, dalam hal ini para pemilik tidak memperkaya dirinya dengan serakah, tetap mengingat untuk hasilnya dengan pihak yang lain, sehingga dapat memperoleh kesejahteraan dan kebahagiaan.

3. Membangun ekonomi yang berkemanusiaan dan berkeadilan, dengan cara memiliki pemahaman terdapat bahaya-bahaya akibat dari keserakahan dan ketamakan. Sebaliknya, memikirkan nilai-nilai luhur dan kebijaksanaan.

4. Dapat mengatur sistem keuangan, baik pemasukan maupun pengeluaran. Seperti halnya yang tertuang di dalam Sigālovada Sutta (DN.31) - penghasilan dibagi menjadi tiga: sebagian digunakan untuk kesejahteraan, sebagian untuk didanakan, dan sebagian dikembalikan sebagai modal atau tabungan.

5. Menghindari pergaulan dan kehidupan yang membawa pada keruntuhan, antara lain: bergaul dengan orang-orang yang jahat, membunuh, mencuri, perzinahan atau seks bebas, menipu, perjudian, minum minuman memabukkan, dan sebagainya.

Dari kedua prinsip tersebut menunjukkan bahwa baik ekonomi Islam maupun Buddhis harus dilakukan dengan mengedepankan nilai-nilai kebaikan dalam ajaran masing-masing. Hal ini menunjukkan adanya korelasi antara Islam dengan Buddhis yang menunjukkan bahwa ekonomi dilakukan dengan cara yang benar dan menyejahterakan semua pihak, serta tidak merugikan diri sendiri, orang lain, makhluk lain, maupun lingkungan sekitar.

\section{Korelasi dalam Sudut Keunggulan.}

Sistematika dari masing-masing agama memiliki spesifikasi tersendiri. Spesifikasi itulah menjadikan keunggulan yang dimiliki dari masing-masing agama sehingga menjadi tolak ukur perbandingan antara masing-masing agama. Dalam segi keunggulan, tentunya ada ciri khas yang sangat menonjol dari setiap agama. Keunggulan yang ditawarkan menjadi daya tarik bagi masyarakat yang ingin menekuni akan ilmu yang tercantum di dalamnya. Keunggulan merupakan suatu bahan promotor yang bertujuan sebagai penjunjung tinggi suatu komunitas. Dengan adanya keunggulan menjadikan elemenelemen masyarakat yakin bahwa hal itu cocok dan mampu untuk menjadi yang terbaik bagi diri mereka.

Dalam Islam terdapat keunggulan dalam ekonomi yang mencakup beberapa hal, yaitu: (1) menjunjung kebebasan individu, (2) mengakui hak individu terhadap harta, (3) mengakui ketidaksamaan ekonomi antar individu, (4) pemerataan distribusi kekayaan, dan (5) menjaga keseimbangan kesejahteraan individu dalam masyarakat.

Sedangkan dalam ekonomi Buddhis terdapat keunggulan yang dimiliki adalah pembentukan ekonomi dilakukan dengan mengembangkan potensi dalam diri mereka. Pengembangan tersebut tentunya didasarkan pada nilai-nilai yang terdapat dalam jalan mulia berunsur delapan yaitu mata pencaharian benar. Selain itu juga pembentukan ekonomi dalam buddhis yang didasari dengan welas asih, sederhana, dan tanpa kekerasan.

\section{KESIMPULAN}

Kehidupan manusia saat ini tidak lepas dari kegiatan ekonomi. Kegiatan tersebut dilakukan demi memenuhi kebutuhan hidup. Dalam kegiatan tersebut pun tentunya ada beberapa hal yang menjadi landasan pikiran, tata cara, dan ilmu tentang berekonomi agar terciptanya kesejahteraan bagi pelakunya. Salah satu agama yang memiliki ilmu tentang ekonomi yaitu Islam. Dalam agama Islam, perekonomian mereka disebut dengan Ekonomi Syariah. Ekonomi syariah adalah segala gejala di masyarakat yang timbul karena 
perbuatan manusia dalam usahanya untuk memenuhi kebutuhan hidup atau untuk mencapai kemakmuran berdasarkan paradigma Islam, yakni suatu ajaran hidup yang bersumber dari al-Qur'an dan Sunnah.

Dengan dilakukannya penelitian ini, maka didapatkan hasil penelitian berupa korelasi antara kedua sudut pandang tersebut. Korelasi antara Ekonomi dalam Islam maupun Buddhis yaitu ekonomi dilakukan dengan usaha tanpa merugikan diri sendiri, orang lain maupun makhluk lain. Dalam sudut pandang agama Buddha ditunjukkan bahwa ekonomi yang dilakukan harus melalui jalan yang benar dan sah, sesuai dengan yang diajarkan yaitu dengan berpedoman pada jalan mulia berunsur delapan yaitu mata pencaharian benar. Ekonomi buddhis tidak hanya mempertimbangkan pada kebahagiaan diri sendiri, melainkan juga memperhatikan pihak lain. Ekonomi syariah maupun Buddhis harus dilakukan dengan mengedepankan nilai-nilai kebaikan dalam ajaran masing-masing.

\section{Daftar Pustaka}

1. Pusat Pengkajian dan Perkembangan Ekonomi Islam Indonesia Yogyakarta atas kerjasama dengan Bank Indonesia.Ekonomi Islam, Jakarta : PT Raja Grafindo Persada.

2. Rivai, Veithzal dan Andi Buchari. 2009. Islamic Economics: Ekonomi Syariah Bukan OPSI, Tetapi Solusi!. Jakarta: Bumi Aksara.

3. Silananda. (2003) Kamma (Hukum Sebab Akibat), Anatta (Doktrin Tiada Inti Diri). Karaniya

4. Sudjana, Nana. Tuntunan Penyusunan Karya Ilmiah. Bandung: CV. Sinar Baru.1988

5. Walse, Maurice. 1995. Kitab Suci Digha Nikaya. Dhammacitta Press.

6. Wijaya-Mukti, K. (2003). Wacana Buddha-Dharma 